\title{
An Analysis of Jargon Used by Receptionists in Front Office at Asa Bali Luxury Villas and Spa Seminyak
}

\author{
I Putu Citra Yudha ${ }^{1}$, I Ketut Seken ${ }^{1}$, \\ Dewa Putu Ramendra ${ }^{2}$ \\ JurusanPendidikanBahasalnggris \\ UniversitasPendidikanGanesha \\ Singaraja, Indonesia \\ e-mail :citrayudha93@gmail.com, iketutseken@gmail.com \\ dewaputuramendra@yahoo.com
}

\begin{abstract}
ABSTRAK
Penelitian ini bertujuan untuk mengidentifikasi dan mendeskripsikan bentuk linguistik, arti dan fungsi jargon yang digunakan oleh resepsionis pada front office di Asa Bali Luxury Villa and Spa Seminyak. Jargon dianalisis dengan menggunakan teori dari Allan \&Buridge (2006), dan di dukung oleh teori Yule 2006, Chaer \& Agustina 2010. Penelitian ini di desain menggunakan metode penelitian kualitatif. Jargon yang di identifikasi adalah jargon yang digunakan dalam bentuk lisan dan tertulis. Tehknik - tehknik yang digunakan dalam mengumpulkan data adalah observasi, dokumentasi dan interview. Dalam hasil penelitian, ditemukan 123 jargon yang digunakan oleh resepsionis di front office Asa Bali Villa and Spa. Dalam bentuk linguistik, jargon jargon yang digunakan oleh resepsionis terdiri dari noun phrases (47 atau $38 \%$ ), abbreviation (30 atau $24 \%$ ), noun (22 atau $18 \%$ ), clipping (5 atau $4.1 \%$ ), affixation (4 atau $3.2 \%$ ), borrowing (4 atau $3.2 \%$ ), acronym (3 or $2.4 \%$ ), preposition phrases (3 or $2.4 \%$ ), verb (2 or $1.6 \%$ ), adjective (2 atau $1.6 \%$ ), coinage (1 atau $0.5 \%$ ). Arti dari jargon -jargon yang digunakan didefinisikan berdasaran interview pada staff villa, dokumen resepsionis, kamus, dan konteks penggunaan jargon. Data analisis menunjukan terdapat dua fungsi jargon, (1) sebanyak 38 data $(29.6 \%)$ menyajikan bahasa yang khusus untuk mengefisienkan komunikasi dan(2) 85 data (70.4\%) meningkatkan solidaritas dalam kelompok. Jargon merupakan sebuah variasi bahasa untuk berkomunikasi di dalam sebuah kelompok.
\end{abstract}

Kata Kunci : jargon, front office department, Asa Bali Luxury Villas and Spa

ABSTRACT

This study aimed at identifying and describing the linguistic forms, the meanings and the functions of jargon used by receptionists of the front office department at Asa Bali Luxury Villas and Spa Seminyak. The jargon was analyzed respectively through Allan \&Burridge's (2006) theory and supported by Yule's (2006) theory, and Chaer\&Agustina's (2010) theory. This study was conducted in qualitative method. The front office jargons were investigated in spoken and written forms. The subjects of this study were receptionists of the front office department at Asa Bali Luxury Villa and Spa Seminyak. The methods of data collection were observation, documentation and interview. This study found that 123 types of jargon were used by receptionists in front office department. It was found that the jargon was in the form of noun phrases (47 or $38 \%$ ), abbreviation (30 or $24 \%$ ), noun (22 or $18 \%$ ), clipping (5 or $4.1 \%$ ), affixation (4 or $3.2 \%)$, borrowing 
( 4 or $3.2 \%$ ), acronym ( 3 or $2.4 \%$ ), preposition phrases (3 or $2.4 \%$ ), verb ( 2 or $1.6 \%$ ), adjective (2 or $1.6 \%$ ), and coinage (1 or $0.5 \%$ ). The meanings of 123 jargon were identified by investigating technical meaning. Besides, this study found that there were two functions of the jargon, (1) providing a technical or specialist language to make communication more efficient and (2) encouraging group solidarity. This study concluded that jargon is a way toexpress the feeling of the community and also have their own specific language.

Keywords : jargon, front office department, Asa Bali Luxury Villas and Spa

\section{INTRODUCTION}

As human beings, people cannot be separated from the process of communication. The most appropriate media to make a communication is a language. Language is a verbal tool which is used for communication (Chaer and Austina, 2010: 11). One of the characteristics of language is being social. It means that language has strong correlation with society. The study about relation between language and society is called Sociolinguistics. Holmes (2001:1) states, sociolinguistics is a major role in language and society. Sociolinguistics studies the relation between language and society and identifies the social function of language. The different societies may have the different languages used or we call language varieties. Wardhaugh(2001: 219) states, language variety can be caused by the social status, age, sex, job or the environment and function. In society, a lot of people use many kinds of language it is called sociolect. One of sociolects is jargon. Allan and Burridge (2006: 56) defines jargon as a specific language in certain circumstances such as profession or other group in which speakers share a common specialized vocabulary, habits of word usage, and forms of expression. Some examples of jargon are used in some jobfield such as military, pilot, hotel, medical field, nursery, etc.

Villa is one of the job-fields that use jargon as a communication. In villa organization, there are some departments or divisions responsible to service guests based on their expert. One of departments in villa is front office department. According to Suwithi\&Boham (2008: 123), Front office department is the major department in a hotel which is situated at the front part of the hotel and its duty is to develop and maintains up to date record on guest information, guest service and ensure guest's satisfaction. The front office is also responsible for welcoming the guests, greeting the guest, handling the guest complaints and connecting all departments in hotel. To do their duty, they need some terms of communication to express their idea and intention. In front office department they usually use words to connect all departments for example "Housekeeping monitor. BersihkanQueen dikamarnomer 3, tamunyasudah CO". Lexically, monitor means computerscreen while in front office, monitor means all employers should be pay attention and ready to work. Queen means a woman who rules a country because she has been born into a royal family, or a woman who is married to a king. In front office, queen refers to a type of bed in which one bed is big enough for two people. $C O$ is kind of abbreviation that stand for Check Out, it means guest has returned the room key to front office and left hotel. People who do not have background about jargon of front office will find difficulty to obtain the message when they are involved in interaction with the member of this division.

In line with the background above, the present study is focused on set of vocabularies in front office that not all people familiar with jargon used in front office. Based on the limitation, the problems of this research are formulated as follows.

(1) What are the linguistic forms of jargon used infront office department at Asa Bali Luxury Villas and Spa Seminyak? (2) What are the meanings of the jargon used 
infront office department atAsa Bali Luxury Villas and Spa Seminyak? (3) What are the functions of jargon used infront office department atAsa Bali Luxury Villas and Spa Seminyak?

Based on the problems, the purposes of study are expected to give information as much as possible to people who wants to learn and interest in front office department. The purposes of study are explained as follow. (1) To identify and analyze linguistic forms of jargon used at front office department in Asa Bali Luxury Villas and Spa Seminyak. (2) To identify and analyze the meanings of each jargon at front office department in Asa Bali Luxury Villas and Spa Seminyak. (3) To identify and describe the function of each jargon used at front office department atAsa Bali Luxury Villas and Spa Seminyak.

\section{RESEARCH METHOD}

This study was conducted in a qualitative research. This study was conducted in Asa Bali Luxury Villa\& Spa, Seminyak. Asa Bali is private pool villa resort which is located in Jln. Yudhistira, Seminyak Bali. The subjects of the study were receptionists in front office department atAsa Bali Luxury Villa and Spa Seminyak. The object of this research is jargon used by receptionists in front office department atAsa Bali Luxury Villas and Spa Seminyak.

In this study, the researcher himself was the main instrument in collecting the data.As the main instrument, the researcher used some tools to obtain the data. The tools were aimed to help the researcher in obtaining the data accurately. First tool is recorder; it was used to collect the data by recording the conversation among employers, interview and also their communication, especially those containing jargon used by the front office community. Second is camera, it was used by researcher in order to obtain and record data about jargon used by receptionists in written form. Third is interview guide, it helped the researcher to interview receptionists at front office department.
This research used three techniques in order to collect the data. The threetechniques, namely: observation, document and interview technique. The researcher used those methods to collect the authentic data from the subjects.In this research, the data that the researcher wants is the jargon that used by receptionists in front office department atAsa Bali Luxury Villas and Spa Seminyak. The step is explained as follow.

(1) Observation technique, Sugiyono (2010:145) defines observation as the basic of all knowledge. The researcher only can work based on data gathered by observation. Observation as a complex process organized from biological and psychological process. In this study the researcher used Non participation observation. This kind of observation did not need observer's participation. This observation was usedto find out the linguistic forms, meanings and functions of the jargon used by receptionists in front office department atAsa Bali Luxury Villas and Spa Seminyak

Documentation technique.Sugiyono (2007: 329) states document is any valuable notes of past events in the form of written text, picture, or monumental creatures the result of research will be reliable if it is supported by documents. In this research documentation was used to collect all document used in front office and take some pictures of jargon used by receptionists in front office department atAsa Bali Luxury Villas and Spa Seminyak in written form.

(3) Interview technique.Sugiyono (2010:231) defines interview as a meeting of two persons to exchange information and idea through question and responses, resulting in communication and join construction of meaning about a particular topic. This technique was aimed to know what are the meanings and functions of jargon used by receptionists in front office department atAsa Bali Luxury Villas and Spa Seminyak.

In data collection process, the researcher used some steps of research 
procedure in order to obtain the data. First is Preliminary observation. Preliminary observation was conducted to make sure that the data needed was there. Second is further observation. Further observation was conducted to find the subject, the researcher began to find several native speakers who expert both in receptionist and speak English. Third step was recording the conversation.After the researcher got the subjects, then the researcher recorded thelanguage that they used in the conversation. The researcher did therecording in several places according to the location of the subjects usingthe jargon. Forth step was transcribing the conversation. The researcher transcribed the conversation into written text in order to avoid many missedinformation that made it error to the research. Fifth step was analyzing the conversation. The step was aimedto explore how the conversations are structured and what kinds of jargons, mechanisms, and rules are including in conversations. Sixth step was interview, it was conducted to informants to help researcher get deeper information about the phenomenon so that the result of observation would be well-understood and resulted to better interpretation during data analysis. And the last step was finding front office's files. Finding front office's files were the complementary data which supported the primary data to make the result of the research more valid.
The procedures of data analysis of this study had done in qualitative method by using interactiveanalysis. Data collection was the first step which was included in observing, recording, and documentingthe informants of those word lists given. Second was data reduction. All of the data were transcribed from the digital recorder into the written form.All the data would be specified, simplified, transformed and grouped. Third is data display. After data reduction, the selected and grouped data based phonemeclassifications were displayed on table. Fourth was drawing verification/conclusion. Based on the data display, the researcher made a conclusion of the research.

In this research, the researcher used triangulation technique to prove the validity and reliability of the data analysis. The researcher used methodological triangulation because it used more than one method to obtain the data in data collection technique such as observation, interview and documentation.

\section{FINDING AND DISCUSSION}

In this research, the researcher found 123 jargon which were used by receptionist in front office at Asa Bali Luxury Villas and Spa Seminyak.

All of result data collection was described and discussed as follow.

Table 4.1.1 The result of data based on linguistic form

\begin{tabular}{|l|l|l|}
\hline No & $\begin{array}{l}\text { Linguistic } \\
\text { Form }\end{array}$ & Amount \\
\hline 1 & Abbreviation & 30 \\
\hline 2 & Acronym & 4 \\
\hline 3 & Affixation & 3 \\
\hline 4 & Borrowing & 4 \\
\hline 5 & Clipping & 5 \\
\hline 6 & Coinage & 1 \\
\hline 7 & Verb & 2 \\
\hline 8 & Noun & 22 \\
\hline 9 & Adjective & 2 \\
\hline 10 & Noun Phrase & 47 \\
\hline
\end{tabular}




\begin{tabular}{|l|l|l|}
\hline 11 & $\begin{array}{l}\text { Preposition } \\
\text { Phrase }\end{array}$ & 3 \\
\hline \multicolumn{2}{|l|}{ Total } & $\mathbf{1 2 3}$ \\
\hline
\end{tabular}

The jargon had been classified and investigated morphologically and semantically according to word process and meaningto answer first and second research question such as: abbreviation, clipping, acronym, affixation, back formation, borrowing, coinage, words and phrases. In investigating linguistic form of jargon, researcher used some theories from Yule (2006: 52-92).

Identifying the meaning of jargon was conducted by investigating technical meaning instead of lexical meaning. The meanings were collected from some sources such as villa front office's document, front office staff interview, front office guide book (Manual) and dictionary.

In this research, researcher found 128 jargons which were used by receptionist in front office at Asa Luxury Villas and Spa Seminyak Bali. Related to the linguistic forms, jargon was investigated based on word formation process such as: abbreviation, clipping, acronym, affixation, back formation, borrowing, coinage, words and phrases. The researcher found form of noun phrase with 47 data (37\%), abbreviation 29 data (23\%) ,noun 22 data (17\%), affixation 5 data (4\%), clipping 5 data (4\%), verb 5 data (4\%), acronym 4 data $(3.1 \%)$, borrowing 4 data (3.1\%) preposition phrase 3 data $(2.3 \%)$, adjective 2 data $(1.7 \%)$ back formation 1 data $(0.5 \%)$ and coinage 1 data $(0.5 \%)$. Noun Phrase places the most frequent one with 47 data $(37 \%)$ because some jargons are constituted from phrases.

(1) Abbreviation

Abbreviation is process of reduction using initialization of words (Yule 2006: 55). Example :FO $\rightarrow$ FO is shortening of Front Office. FO had experienced a process of reduction using initialization of words Front + Office into $\mathbf{F}$ and O. Then, booth latters are joined together into FO which has meaning a hotel employee whose responsibilities center on the registration process, but also typically include preregistration activities, room status coordination, and mail, message, and information requests.

Example :Receptionist 1: FO monitor! Tolong handle check in group di Abian 1! (attention Front office! Please handle check in group in room Abian 1)

\section{(2) Acronym}

According to Yule (2006: 57) acronym is the result of forming a word from the first letter or letters of each word in a phrase. Acronym is one of the abbreviations or shortening process and it can be pronounced into a new single word. Exanple $:$ VIP $\rightarrow$ VIPis taken from Very Important Person. VIP is formed by a process of taking every first initial of words Very + Important + Person into $\mathbf{V}+\mathbf{I}+\mathbf{P}$. Then the letters are joined together and can be pronounced into a new single word VIP. It meansa special person or guests who stays in villa. (governor, celebrity, head of company etc.) Example :

Receptionist 1 : Sebentartolong handle adaVIP guest check in di CR 2 temennyapakAgusdari Australia. (Please handle VIP guest, he is Mr. Agus's friend from Australia.)

\section{(3) Affixation}

Yule (2006: 54) states that affixation is the adding of affixes (prefix, infix, suffix) to the root of word in order to fashion new word. Example :Repost $\rightarrow$ The word repost is derived from root post. Repost is formed by adding prefix re- to the root post, $(r e-+$ mark = post $)$. Prefix remeans a second or subsequent, while root post means broadcast to public. In conclusion, the word repost in front office jargon means a second or subsequent a posting (a message, room price, guest order, room service and charge) to Hotel Visual Program (VHP), for a second or further time.Example :Receptionist 2 : Dek input bill di VHP sekalianrepostyang kemarinmalem. Untukbesokjuga, remark order tamunyaya. (Please input the bill in Visual Hotel Program, 
and repost the previous bill. And also please remark guest order for tomorrow)

\section{(4) Borrowing}

Borrowing is one of the word formation processes to create new words by taking from other language (Yule 2006: 54). Example: Abian $\rightarrow$ Abian is original word from Balinese which has meaning a tropical Balinese zen-garden. However in front office jargon abian means the name of Asas's double size room.Example :Receptionist 1: FO monitor! Tolong handle check in group di Abian 1! (Front office attention! Please handle check in group in room Abian 1).

\section{(5) Clipping}

Clipping is a process of new words by shortening the polysyllabic word or by deleting one or more syllables (Yule, 2006: 55). Example: cat $\rightarrow$ cattaken from category. The word catagory is formed by a process of back-clipping or deleting syllables in back of the word (cat egory) into cat. This word has meaning as a room status term indicating that the category of overview, size and name of room in villa. Example :

Receptionist 4 :Mbok guest atasnamaJoongsiHoon order Room cat CR2 NSR - HMP benerkan? Biarenggaksalah input di VHP. (JoonsiHoon order room category Carik 2, Non Smoking Room, Honeymoon Package isn't it? It is aimed to avoid error input in VHP)

\section{(6) Coinage}

Yule (2006: 53) states that coinage word is the invention of totally new terms. Example :Bluebird $\rightarrow$ Bluebird is the first taxi company in Bali since 25 years ago. Bluebird is used to call or order taxi trough FO in order to pick up guest and return to villa. Example :Receptionist 2: TelfonBluebirdsekalianDek. (Kadek, please call a taxi)
(7) Words

Word is a speech sound or combination of sounds having meaning and used as a basic unit of language and human communication. It consists of nouns, verbs, adjectives, and adverbs. Example $:$ Check $\rightarrow$ Check is classified as a verb. In front office jargon, the word check is used as an act to examine something in order to determine its accuracy, quality, or condition, or to detect the presence of something. Example :Receptionist 1: check summary cashier report, cocokinsama journal of transaction-nya. (please check summary cashier report and then match with the journal transaction).

(8) Phrase

According to Yule (2006: 72) a phrase is a group of words which form a grammatical unit, has a main word that is called a head. It is the only word that has to occur in the phrase. A phrase does not contain a finite-verb and does not have a subject-predicate structure. The modifier, putting before the head is called premodifier. The modifier, putting after the head is called post-modifier. There are five kinds of phrase namely; noun phrase, verb phrase, adjective phrase, prepositional phrase and adverbial phrase. Example $:$ Arrival Guest List $\rightarrow$ Arrival Guest List is classified as noun phrase. The head of phrase arrival guest list is list. It is formed by process adding pre modifier arrival (adj)+ guest (n) into the head list (n), then they stand together into arrival guest list. In front office jargon, the phrase arrival guest list means a form list indicating that the guest would arrive to the villa. Example :

Receptionist 5: Manaarrival guest listsama transportation schedulenya? Mau escort kebandara pick up tamu. (Where are arrival guest list and transport schedule? I would like to pick guest up in airport.)

\subsubsection{The result of data based on function of jargon}

\begin{tabular}{|l|l|l|l|}
\hline No & Function of Jargon & Amount & Percentage \\
\hline 1 & $\begin{array}{l}\text { Providing a technical language for } \\
\text { efficient communication }\end{array}$ & 38 & $29.6 \%$ \\
\hline
\end{tabular}




\begin{tabular}{|l|l|l|l|}
\hline 2 & Encouraging in-group solidarity & 85 & $70.4 \%$ \\
\hline Total & 123 & $100 \%$ \\
\hline
\end{tabular}

In term of function Allan and Burridge (2006: 58) propose two functions of jargon. Firstly, a jargon functions in providing a technical language for efficient communication. The second function is encouraging in-group solidarity.

The data analysis of jargon used infront office atAsa Bali Luxury Villas and Spa Seminyakshowed two functions of jargon, first is providing a technical language for efficient communication with 38 data (29.6\%)

\section{Example :NSR (Non Smoking Room) $\rightarrow$} NSR (Non Smoking Room) is a villa room status that indicates guest in villa not allowed smoking in room. The motive or function of front office used this word because they felt more efficient to pronoun or easier to communicate with other staff. Example :

Receptionist 4 :Mbok guest atasnamaJoongsiHoon order Room cat CR2 NSR - HMP benerkan? Biarenggaksalah input di VHP. (JoonsiHoon order room category Carik 2, Non Smoking Room, Honeymoon Package isn't it? It is aimed to avoid error input in VHP). From the example it can be concluded that receptionist used this term to make communication easier rather than used the full words.

The second function is encouraging in-group solidarity with 90 data (70.4\%).Example :Summary cashier report $\rightarrow$ Summary cashier report means Summary reports of transactions. A form of record of amounts received. The motive or function of front office used this word because they can encourage in-group solidarity. Example :

Receptionist 1 :check summary cashier report, cocokinsama journal of transactionnya. (please check summary cashier report and then match with the journal transaction) Receptionist 3: lya Pak. Astungkaragakadayang miss. (Yes sir hopefully there is no miss input.) From the example, it can be concluded that each employee knows what their job and they share same unity thus the solidarity is upgraded.

\section{CONCLUSION}

In this research, researcher found 128 jargons which were used by receptionist in front office atAsa Bali Luxury Villas and Spa Seminyak. The researcher found form of noun phrase with 47 data (37\%), abbreviation 29 data (23\%) ,noun 22 data (17\%), affixation 5 data (4\%), clipping 5 data (4\%), verb 5 data (4\%), acronym 4 data $(3.1 \%)$, borrowing 4 data $(3.1 \%)$ preposition phrase 3 data $(2.3 \%)$, adjective 2 data $(1.7 \%)$ back formation 1 data $(0.5 \%)$ and coinage 1 data (0.5\%). Noun Phrase places the most frequent one with 47 data $(37 \%)$ because some jargons are constituted from phrases. Allan and Burridge (2006: 58) In terms of meaning, which is elaborated from lexical meaning and the context where the jargons are used, it implies that the jargons have technical meaning and are likely similar or different among other villas or hotels. In terms of function, most jargons are used to encourage in-group solidarity. It implies that using the jargons, the front office at Asa Bali Luxury Villas and Spa Seminyakare able to maintain the team spirit and confidence because other regards the receptionists have unique and specific technical terms.

The front office jargons become the technical term at Asa Bali Luxury Villa AndSpa Seminyakand they are created for communication purpose. They are used based on the agreement between the board in Front Office Department including the FOM (Front Office Manager), Supervisor, GSA (Guest Service Assistant) and bell boy. They are presented in particular pattern in order to avoid the misunderstanding among receptionists.

\section{SUGGESTION}


Based on the result of the study, it can be suggested some points to the following parties. (1) Students of English Education Department. The students of English Education Department are expected to have better understanding on language variation and front office jargon in a hotel. The understanding might improve their competence in learning ESP and Sociolinguistics especially in language variation. (2) Lectures in English Education Department.This research is expected to contribute as a teaching and learning resource or material in relation to language variation and ESP course. (3) The Front Office Department. This research is expected to be a resource of receptionists as well as management board of an international class villa in relation to develop the villa service and accommodation. (4) Other Researchers. This research is also expected to provide alternative resources to support other researchers in conducting research in same field; sociolinguistics discipline,especially in language variation. Other researchers are suggested to dig deeper cases concerning the sociolinguistics in language variation.

\section{REFRENCES}

Allan, K,\&Burridge, K. 2006 ForbidenWords : Taboo and the Censoring of Language. Cambridge: Cambribge University Press.
Chaer, A \&Agustina, L. 2010.SoociolinguisticPerkenalanAwal. RinekaCipta. Jakarta.

Fromkin, V. Rodman, R. and Hyams, N 2003.An Introduction to Language.Seventh Edition. United States: Wadsworth Thompson US.

Holmes, J. 2001. An Introduction to Sociolinguistics.Second Edition. London: Longman. Inc.

Miles, Mattew and Huberman,Michael. 1994. Qualitative Data Analysis. London: Sage Publications.

Rutherford, D. G. and Michael, J. O. 2007. Hotel Management and Operations.Fourth Edition. New Jersey: John Wiley \& Sons, Inc.

Sugiyono. 2010. MetodePenelitianKuantitatifKualitatifd an $R \& D$. Bandung: Alfabeta

Suwithi, W. N. \&Boham. C. E 2008. AkomodasiPerhotelan 1, 2, dan 3 untuk SMK Pariwisata. Jakarta: DirektoratPembinaanSekolahMeneng ahKejuruan, DirektoratJendralManajemenPendidik andasardanMenengah, DepartemenPendidikanNasional.

Wardaugh, R. 2006. An Introduction to Sociolinguistics: Forth Edition. Oxford: Blackwell Publishing.

Yule, G. 2006. The Study of Language.3rd Edition.Cambrige University Press. 